\title{
Needs Assessment of Teaching Book Development Based on Plants Multiplication Research in Plant Tissue Culture Course
}

\author{
Fauziyah Harahap \\ Biology Departement, Faculty of \\ Mathematics and Natural Sciences \\ Universitas Negeri Medan \\ Medan, Indonesia \\ fauziyahharahap@gmail.com \\ Nanda Eska Anugrah Nasution \\ Biology Education Department, Faculty \\ of Education and Teacher Training \\ Institut Agama Islam Negeri Jember \\ Jember, Indonesia \\ eskanasution@gmail.com
}

\author{
Harifah Insani \\ Biology Education Department \\ Universitas Negeri Medan \\ Medan, Indonesia \\ harifahinsani1@gmail.com
}

Roedhy Poerwanto

Center for Tropical Horticulture Studies

Bogor Agricultural University, IPB

Bogor, Indonesia

roedhy8@yahoo.co.id

\author{
Diky Setya Diningrat \\ Biology Departement, Faculty of \\ Mathematics and Natural Sciences \\ Universitas Negeri Medan \\ Medan, Indonesia \\ dikysetyadiningrat@gmail.com
}

\author{
Rifa Fadhilah Munifah Hasibuan \\ Agronomy and Horticulture Department \\ Bogor Agricultural University, IPB \\ Bogor, Indonesia \\ rifafadhilah25@gmail.com
}

\begin{abstract}
Teaching books are a source of information, tools and teaching materials that are arranged systematically and used in learning process. The purpose of this study was to analyze the need for developing teaching books based on in vitro multiplication of Sipahutar pineapple plants in tissue culture courses. This research method was quantitative descriptive with 44 students as sample from Biology Department of Faculty of Science, Universitas Negeri Medan (Unimed). This research used four-D Models by Thiagarajan. The steps in this research, namely Define, consists a) Front-end analysis, b) Student characteristics analysis, c) Concept analysis, d) Tasks Analysis e) Learning objectives. Data collection was done by distributing open questionnaires. The results indicated that a) The initial preliminary analysis and curriculum shown that students still have difficulty understanding of plant tissue culture material, b) $72 \%$ of students had never read research-based teaching books on tissue culture courses, $90 \%$ of students agreed with the research-based teaching book c) Concept analysis shown that previous learning has not accommodated the entire curriculum structure, procedural content, the material was not yet research based, d) Completion of tasks, especially those based on research has not been done, e) The need of a variety of learning resources, it was very necessary to develop researchbased teaching books.
\end{abstract}

Keywords: needs assessment, research-based teaching books, pineapple, in vitro

\section{INTRODUCTION}

Innovation in the learning process was done to provide improved learning has been done by experts. Forms of development in learning can be in the form of development of models, methods, learning media and teaching books. The entire development was carried out to improve student understanding of learning material. In addition to cognitive aspects, learning development must also include psychomotor and affective. In connection with learning outcomes based on the parameters of the Kerangka Kualifikasi Nasional Indonesia (KKNI) that students majoring in biology education have an understanding of Modern Biology, are able to apply, understand or solve problems that develop in society, are willing and able to follow scientific developments and have adequate life skills.

Innovation and development of learning resources was very much needed considering that lecturers are very instrumental in the teaching and learning process in the classroom, should be able to cultivate their ability to produce effective and efficient learning resources. Learning resources are all supporting resources for learning activities, including textbooks.

In learning activities, students not only interact with the teaching staff as one source, but include interactions with all learning resources that allow them to be used to achieve the desired results as in [1].

Teaching materials have various forms and types, one of the printed teaching materials that are often used by students is textbooks. Textbooks are a set of subject matter material that is arranged systematically displaying the integrity of the competencies that will be mastered by students in learning activities as in [2]. With the existence of textbooks, it allows students to learn coherently so that they master a competency as a whole as in [3].

Teaching books are a set of materials, subject matter, which are arranged systematically displaying the integrity of the competencies that will be mastered by students in learning activities as in [2]. With the existence of teaching books, it allows students to learn coherently so that they master a complete competency as in [3].

Teaching books have an important role in the learning process so that it can improve student learning achievement and be able to improve student character.

In addition to textbooks, there are also known instructional sheets with various names, including: job sheets, worksheets, information sheets and other teaching materials. print or nonprint. 
Innovation of learning resources for plant tissue culture materials, especially for lectures, is very necessary to complete student references in developing their knowledge of plant tissue culture. Along with efforts to increase student knowledge about plant tissue culture, learning innovation is one of the things that must be considered, to improve teaching and learning process. Students will be more invited to discuss, interact, and dialogue so that they are able to construct their own scientific concepts and rules as in [4].

Plant tissue culture is one of the courses found at Universitas Negeri Medan. The material in plant tissue culture contains material that is conceptual, procedural (process), hierarchy of thinking, so it is demanded to be able to develop new things that can expand knowledge. Several learning tools have been developed such as making tissue culture animation media as in [5], making media in the form of network culture learning videos as in [6]. The initial material of tissue culture discusses the cell theory that underlies the development of tissue culture, the concept of totipotence, laboratory design, plant breeding in vitro, the use of in vitro techniques for the advancement of entrepreneurship science and culture as in [7]. Tissue culture techniques can help exploit a network or plants to regenerate rapidly and can be arranged according to today's modern needs. The development of science and technology should also be accompanied by developments in the field of education. Because the material discussed emphasizes more on the dimensions of the process so that learning by experiment is very suitable to be able to develop students' knowledge and skills, and be able to discover for themselves the basic concepts of tissue culture. To support this, researchbased textbooks need to be developed.

Textbooks are developed in accordance with curriculum development, learning outcomes, and the implications of science and technology development. Research-based textbook development is an activity to expand and deepen the material applicative. The material presented not only includes the basic concepts but also contains the facts obtained through the research conducted. Textbooks that are developed based on research results are contextual, deeper, more interesting because the material presented does not only contain basic concepts but facts that are scientifically proven. Textbooks that are equipped with effective research results are used in learning because they are more applicable and meet the present element. In the field of tissue culture, research-based textbooks are still very limited. It is very necessary to develop research, compilation of research-based textbooks. Especially teaching books based on multiple plants research in plant culture culture cource. This is consistent with the results of previous as in [8] developed an evolution textbook as in [9] developed a biotechnology textbook, as in [10] developed an animal physiology textbook, and as in [11] developed an animal development textbook. Each of these studies is research based and is written in the form of textbooks so that it can be used as additional reading material for students.

The model of instructional system development / teaching tool based on invitro plant multiplication research used in this study was the 4D (Define, Design, Development and Dissemination) model of Tiagarajan. This paper conveys the first stage of $4 \mathrm{D}$, the Define stage. This Define Phase includes five main steps 1) Final initial analysis, 2) Analysis of student characteristics, 3) Concept analysis, 4) Task analysis, 5) Formulation of learning objectives [12].

Front-end analysis. This analysis aimed to bring up and determine the basic problems faced in learning plant tissue culture, so it was necessary to develop a textbook based on in vitro plant breeding research, especially in vitro plant propagation. With this analysis will get a picture of facts, expectations and alternative solutions to basic problems, which makes it easier in determining or selecting textbooks that are developed.

Student analysis (learner analysis). Student analysis was a study of the characteristics of students in accordance with the design of the development of textbooks. These characteristics include background knowledge, cognitive development and skills. The results of the analysis of the characteristics of these students will be used as a reference frame in compiling textbooks based on research on the propagation of pineapple plants in vitro.

Concept analysis. This stage was done to identify the main concepts to be taught. The analyzes that need to be done are (1) analysis of learning outcomes aimed at determining the type of textbooks, (2) analysis of learning resources, i.e. gathering and identifying which sources support the preparation of textbooks.

Task analysis. The task analysis was carried out an analysis of the main skills that are adequate and necessary. This analysis is to ensure the complete fulfillment of the tasks contained in the textbook.

Formulation of Learning Objectives (specifying instructional objectives). Before writing teaching materials, learning objectives and competencies to be achieved are formulated in advance. It is intended that the textbooks developed do not deviate from the original purpose.

\section{METHOD}

The study was conducted at the Department of Biology Education, FMIPA Universitas Negeri Medan (UNIMED), from November 2017 to August 2019. The sample in this study were students of semester VII who were taking tissue culture courses. This research was belong to quantitative descriptive research. The model of textbook development based on plant multiplication research that was used in this study was the 4D model from Tiagarajan (1974) as in [12]. This paper conveyed the first stage of 4D, the Define stage. This Define Phase includes five main steps, 1) The initial analysis (front-end analysis), 2) Students characteristics analysis, 3) Concepts analysis, 4) Assignments analysis, 5) Formulation of learning objectives.

Data collection techniques were carried out by using questionnaires, observation and open interviews.

The initial analysis, based on 9 indicators. Analysis of student characteristics was examined using a questionnaire with 7 indicators.

Concept analysis, including analysis of learning achievements, concepts needed and analysis of learning resources, by collecting and identifying sources that support the preparation of textbooks. 
Task analysis, obtained by analyzing the curriculum (semester learning plan, RPS), to obtain key skills data needed, to ensure the tasks contained in the textbooks. The formulation of Learning Objectives is carried out by analyzing the (semester learning plan, RPS) of plant tissue culture courses in the Biology Department, Faculty of Science Unimed. Data were analyzed in descriptively quantitative.

\section{RESUltS AND DISCUSSION}

\section{A. Front-end analysis}

Based on the results of an analysis conducted the need for research-based textbooks in vitro Sipahutar pineapple plant propagation in tissue culture courses shown that: (a) the need for learning resources obtained $86 \%$ of students agree with the variety of learning resources; (b) tissue culture books linking research obtained, $72 \%$ of students stated that their tissue culture books have not linked research; (c) interest in research-based textbooks was obtained, $90 \%$ of students expressed their agreement with the research-based textbooks for the propagation of Sipahutar pineapple plants in vitro.

In the process of learning activities, students used books as learning resources. References [13] states that textbooks are the type of books used in learning and teaching activities. Textbooks are arranged with flow and logic in accordance with the learning plan, according to student learning needs and to achieve specific learning goals or competencies. With the existence of textbooks, the process of teaching and learning activities will become smoother and more effective.

\section{B. Students Characteristic Analysis}

The results of the analysis of student characteristics were obtained by all students who took tissue culture courses from the science department while in high school. It can be understood because all respondents came from biology majors. To study this tissue culture lecture material, basic biochemistry, plant anatomy, physiology and biotechnology are needed, where at this stage cognitive development and skills are maximally acquired.

Things to do during spare time are various; watching, reading a book, traveling. But from the interview results obtained $61 \%$ of students said they have a research-based book in addition to tissue culture to explore advanced knowledge and $100 \%$ of students can write 15 vocabularies of tissue culture in a short time.

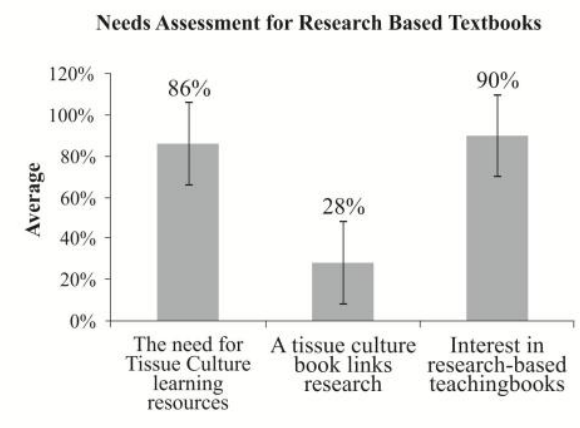

Fig. 1. The initial preliminary results and analysis of the need for teaching books based on research on multiplication of Sipahutar pineapple plants in vitro
TABLE I. CHARACTER ANALYSIS RESUlTS OF UNIVERSITAS NEGERI MEDAN STUDENTS

\begin{tabular}{|c|c|c|c|}
\hline No & Aspects & Characters & $\begin{array}{c}\text { Percentage } \\
(\%)\end{array}$ \\
\hline \multirow[t]{2}{*}{1} & \multirow[t]{2}{*}{ Majors in High school } & Nature Science & 100 \\
\hline & & Social Science & - \\
\hline \multirow[t]{2}{*}{2} & \multirow[t]{2}{*}{ Sex } & Male & - \\
\hline & & Female & 100 \\
\hline \multirow[t]{2}{*}{3} & \multirow[t]{2}{*}{ Mother tongue / native language } & Bahasa Indonesia & 93,3 \\
\hline & & Local language & 6,7 \\
\hline \multirow[t]{4}{*}{4} & \multirow[t]{4}{*}{ Parents job } & Entrepreneur & 53 \\
\hline & & $\begin{array}{l}\text { Civil employee } \\
\text { (PNS) including } \\
\text { lecturer and } \\
\text { teacher }\end{array}$ & 27 \\
\hline & & $\begin{array}{c}\text { State-owned } \\
\text { enterprises, } \\
\text { General employees }\end{array}$ & 13 \\
\hline & & others & 7 \\
\hline \multirow[t]{4}{*}{5} & \multirow[t]{4}{*}{ Things to do in spare time } & $\begin{array}{c}\text { Watching in } \\
\text { cinema }\end{array}$ & 33,33 \\
\hline & & Doing homework & 40,00 \\
\hline & & Read some books & 20,00 \\
\hline & & Watching TV & 6,67 \\
\hline \multirow[t]{3}{*}{6} & \multirow[t]{3}{*}{$\begin{array}{l}\text { Things done with friends to fill } \\
\text { spare time }\end{array}$} & $\begin{array}{l}\text { Travelling and } \\
\text { eating }\end{array}$ & 13,33 \\
\hline & & Study group & 46,67 \\
\hline & & others & 33,33 \\
\hline 7 & $\begin{array}{c}10 \text { scientific language } \\
\text { vocabularies related to tissue } \\
\text { culture }\end{array}$ & $\begin{array}{l}\text { All respondents } \\
\text { can write tissue } \\
\text { culture } \\
\text { vocabularies }\end{array}$ & 100 \\
\hline
\end{tabular}

From the data in Table 1, the dominant occupation of parents $(53 \%)$ was self-employed. Only $27 \%$ belonged to civil employee/Pegawai Negeri Sipil (PNS). The educational background of parents, work, and social level in the community will affect the mindset of someone, therefore the characteristics of biology majors who were respondents in this study illustrate that, students were able to write 15 tissue culture vocabularies in a short time, an indication that this material was very liked and needed.

\section{Concept Analysis}

Based on researcher experiences as a plant tissue culture lecturer for over ten years and students learning achievement during these years, a lot of students have learning difficulties in plant tissue culture course, as many students pass this course with poor final scores. Students have difficulties in learning plant tissue culture course in university due to lack of learning aid in understanding the course optimally. This research aims to understand the learning difficulties of students and in improving their learning achievement. Plant tissue culture course as a science-based course makes good science to process skills that are needed for every student to improve his learning achievement in this course. Creating a learning environment that concerns the science process skills of students is one of the lecturer's responsibilities. This responsibility is separate from improving the learning achievement of students of the course as in [14].

The material discussed in the plant tissue culture course was to develop science and skills by conducting a study of the basic concepts of tissue culture, starting from the history of its development, tissue culture laboratory facilities and the 
principle of sterilization, types of tissue culture to the application of in vitro culture. So it will be easier if there were learning resources that can cover all of the materials, namely research-based teaching books. The availability of research-based teaching books was still very lack. This was evidenced by the results of the analysis of tissue culture books that link research was still low. Based on the analysis of concepts and learning outcomes of courses, shown that previous learning has not accommodated the entire curriculum structure, procedural content, the material was not yet research based.

After examining the material in tissue culture courses, it was known that the material being taught emphasized more on the process dimension. Thus the learning material developed was the material contained in tissue culture courses with the topic of pineapple plant propagation in vitro in accordance with the learning outcomes in tissue culture courses.

The material discussed in the plant tissue culture course is to develop science and skills by conducting a study of the basic concepts of tissue culture, starting from the history of its development, tissue culture laboratory facilities and the principle of sterilization, types of tissue culture to the application of in vitro culture. So it will be easier if there were learning resources that can cover all of the material, namely research-based teaching books. The availability of research-based textbooks was still very lack. This was proven by the results of analyzes of tissue culture books that link research was still low. Based on the analysis of concepts and learning outcomes of courses, shows that previous learning has not accommodated the entire curriculum structure, procedural content, the material was not yet research based.

After examining the material in tissue culture courses, it was known that the material being taught emphasizes more on the process dimension. Thus the learning material developed was the material contained in tissue culture courses with the topic of pineapple plant propagation in vitro in accordance with the learning outcomes in tissue culture courses.

Student learning resources were still limited, students have not maximized the full potential of existing learning resources to support understanding of tissue culture material.

\section{Task Analysis}

Task analysis, obtained by analyzing the Semester Study Plan / Rencana Perkuliahan Semester (RPS). The types of tasks that have been carried out at the UNIMED Biology Education Department are Routine Tasks, Critical Book Review, Critical Journal Report, Mini Research, Engineering Ideas, Projects. Completion of tasks, especially those based on research has not been done, was very necessary to develop research-based teaching books, especially In Vitro Plant Breeding, Growth of Pineapple Sipahutar in vitro.

In the learning process, students not only interact with students, but also with other learning resources, one of which is teaching material. In connection with efforts to achieve competence, students need to take experience, practice, and look for certain information. One of the tools that can be used to achieve these competencies is to use teaching materials as learning resources in the lecture process with the aim of helping to facilitate the learning process. Textbooks or textbooks are chosen because they contain material about specific subjects or fields, which are arranged systematically and have been selected based on specific objectives, learning orientation and student development to be assimilated. Exposure to the problem or subject matter (subject matter) in the textbook is also relatively thorough so it is expected that students' understanding of a material can be more in-depth and complete. Textbooks are also structured for instructional purposes which are complemented by means of teaching that are harmonious and easily understood by the users in schools and colleges so that they can support a teaching program as in [15].

\section{E. Formulation of Learning Objectives}

The formulation of Learning Objectives was carried out by analyzing the Semester Study Plan / Rencana Perkuliahan Semester (RPS) of plant tissue culture courses in the Biology Department, FMIPA UNIMED. The need for a variety of learning resources, it was very necessary to develop research-based teaching books. The existing network culture teaching book still emphasized the dimensions of content and the unavailability of research-based textbooks, especially the growth of pineapple plants in vitro.

If students lack on reading material, in the end students look for reading material from the internet. As we all know that not all material available on the internet contains true and valid information. Such conditions resulted in several students experiencing misconceptions. Misconceptions are students' understanding that is different from definitions and explanations that are believed to be true by scientists. Misconception can be described as a wrong understanding of ideas, objects, or events that are arranged based on one's experience as in [16].

Research integrated into the teaching book source will provide excellence for students in the context of developing meta cognition and achieving competence. Students were able to think critically and analytically, evaluate information, and solve problems, and competence in carrying out and evaluating research that was very useful and helps in professional development that prioritizes innovation and excellence as in [17]. Continuation in this research is to develop textbooks based on research in propagation of Sipahutar pineapple plants in vitro. Textbooks are arranged systematically according to the stages of implementing plant propagation in vitro. In addition, the book also contains the results of research that has been done by the author himself and the discussion. So that it can motivate students to be able to do other research related to tissue culture.

Research-based teaching book development was an activity to expand and deepen the material applicatively. The material presented not only included the basic concepts but also contained the facts obtained through the research conducted. Textbook was developed based on research results are contextual, deeper, more interesting because the material presented does not only contain basic concepts but facts that are scientifically proven as in [18].

Textbooks equipped with effective research results were used in learning because they are more applicable and meet the present elements as in [19]. The development of 
research-based textbooks was expected to help students to know the development of research and the latest discoveries related to plant tissue culture courses in pineapple plant multiplication as in [20].

\section{CONCLUSION}

Based on the results of the needs assessment analysis for research-based textbooks, it can be concluded that the existing textbooks still emphasized the content dimension. The unavailability of research-based teaching books. In connection with learning outcomes based on the parameters of the Indonesian National Qualification Framework / Kerangka Kualifikasi Nasional Indonesia (KKNI), it was very necessary to develop research-based teaching books which contain research results.

\section{ACKNOWLEDGMENT}

The authors would like to thank for being funded by the Kemenristek Dikti through the research grant PDUPT 2018 budget year, with Contract Number, No: 027/UN 33.8/LL/2018.

\section{REFERENCES}

[1] Supriadi, "Pemanfaatan sumber belajar dalam proses pembelajaran,". Lantanida Journal, vol. 3(2), 2015, pp. 1-10.

[2] A. Prastowo, Panduan kreatif membuat bahan ajar inovatif, Jogjakarta: DIVA Press, 2005.

[3] E.S. Millah, S.B. Lukas, and Isnawati, "Pengembangan buku ajar materi bioteknologi di kelas XII SMA Ipiem Surabaya berorientasi sains, teknologi, lingkungan, dan masyarakat (SETS)," BioEdu, 1(1), 2012, pp. 19-24.

[4] U. Mansyur, "Inovasi pembelajaran bahasa indonesia melalui pendekatan proses," Jurnal retorika, 9 (2), 2016, pp. 90-163.

[5] Harahap, "Pembuatan dan penerapan media animasi sebagai upaya untuk meningkatan kompetensi mahasiswa biologi pada materi kultur jaringan," Jurnal Pendidikan Biologi, vol 1(3), 2010, pp. 161-171

[6] Harahap, Video pembelajaran kultur jaringan, Unimed. Medan: Hak cipta No. 000126111, 2018.

[7] Harahap, Kultur jaringan tanaman, Medan: Unimed Press, 2011.
[8] R.E. Fadilah, M. Amin, and U. Lestari, "Pengembangan buku ajar evolusi berbasis penelitian untuk mahasiswa S1 Pendidikan Biologi Universitas Jember," Jurnal Pendidikan, vol. 1(6), 2016, pp. 11041109.

[9] A. Pambudiono, E. Suarsini, and M. Amin, "Pengembangan buku ajar bioteknologi berbasis penelitian bioremidiasi logam berat kadmium untuk mahasiswa S1 Biologi Universitas Negeri Malang. Jurnal Pendidikan, vol. 6(1), 2016, pp. 1077-1085.

[10] C.N. Primiani, "Pengembangan buku ajar berbasis penelitian bahan alam lokal sebagai estrogenik pada mata kuliah fisiologi hewan," Prosiding Mathematics and Science, FMIPA IKIP PGRI Madiun, 2014.

[11] S.D.K. Putro, U. Lestari, and B. Lukiati, "Pengembangan buku ajar perkembangan hewan berbasis penelitian metamorfosis ulat sutera Bombyx mori L.," Jurnal Pendidikan, vol. 1(7), 2016, pp. 1229-1234.

[12] S. Thiagarajan, D.S. Semmel, and M.I. Semmel, Instructional development for training teachers of expectional children, Indiana: Indiana University Bloomington, 1974..

[13] S. Arifin, and A. Kusrianto, Sukses menulis buku ajar dan referensi, Surabaya: Grasindo, 2018

[14] F. Harahap, N.E.A. Nasution, and B. Manurung, "The effect of blended learning on student's learning achievement and science process skills in plant tissue culture course," International Journal of Instruction, vol. 12(1), 2019, pp. 521-538.

[15] I. Pratiwi, F. Rahman, D. Listyorini, "Analisis kebutuhan buku biologi mangrove untuk matakuliah biologi kelautan dan ekologi wilayah pesisir di Universitas Tadulako Palu," Prosiding Pendidikan IPA Pascasarjana UM. Pascasarjana Universitas Negeri Malang, 2017.

[16] D. Setiawan, "Analisis kebutuhan buku ajar taksonomi tumbuhan berbasis pendekatan konstruktivisme bagi mahasiswa Program Studi Pendidikan Biologi IKIP Budi Utomo Malang," Prosiding Seminar Nasional Hayati V 2017, FMIPA IKIP Budi Utomo Malang, 2017.

[17] A.B. Pratama, "Jurnal ilmiah sebagai bahan pembelajaran berbasis riset pada Pendidikan Sarjana Administrasi Negara. Journal of Public Administration and Local Governance, vol. 1(1), 2017, pp. 10-19.

[18] Primiani, "Meningkatkan aktivitas dan prestasi belajar biologi melalui pendekatan kontekstual dengan media herbarium dan insektarium. Pedagodia, vol. 13(1), 2009, pp. 71-77.

[19] U. Nuha, M. Amin, and U. Lestari, "Pengembangan buku ajar berbasis penelitian evolusi dan filogenetik molekuler untuk matakuliah evolusi di Universitas Jember," Jurnal Pendidikan, vol. 1(9), 2016, pp.1791-1796.

[20] D.T. Widayati, D. Luknanto, E. Rahayuningsih, G. Sutapa, R.P. Sancayaningsih, and Sajarwa. Pedoman umum pembelajaran berbasis riset (PUPBR), 2010. 